\title{
Molecular Characterization and Diagnosis of QoI Resistance in Cucumber and Eggplant Fungal Pathogens
}

\author{
H. Ishii, K. Yano, H. Date, A. Furuta, Y. Sagehashi, T. Yamaguchi, T. Sugiyama, K. Nishimura, and W. Hasama
}

First, seventh, and eighth authors: National Institute for Agro-Environmental Sciences, Tsukuba, Ibaraki 305-8604, Japan; second author: Kochi Agricultural Research Center, Nankoku, Kochi 783-0023, Japan; third author: Agricultural Experiment Station, Okayama Prefectural General Agriculture Center, Sanyo, Okayama 709-4602, Japan; fourth author: Saga Prefectural Agricultural Research Center, Saga, Saga 840-2205, Japan; and fifth and sixth authors: BML Inc., Kawagoe, Saitama 350-1101, Japan; and ninth author: Oita Prefectural Agricultural Research Center, Usa, Oita 872-0103, Japan.

Accepted for publication 7 June 2007.

\begin{abstract}
Ishii, H., Yano, K., Date, H., Furuta, A., Sagehashi, Y., Yamaguchi, T., Sugiyama, T., Nishimura, K., and Hasama, W. 2007. Molecular characterization and diagnosis of QoI resistance in cucumber and eggplant fungal pathogens. Phytopathology 97:1458-1466.

The molecular mechanism of QoI fungicide resistance was studied using isolates of cucumber Corynespora leaf spot fungus (Corynespora cassiicola) and the eggplant leaf mold (Mycovellosiella nattrassii). In both pathogens, a mutation at position 143 from glycine to alanine (G143A) was detected in the cytochrome $b$ gene that encodes for the fungicide-targeted protein. Moreover, the nucleotide sequence at amino acid position 143 was converted from GGT or GGA in sensitive (wildtype) to GCT or GCA in resistant (mutant-type) isolates. The methods of polymerase chain reaction restriction fragment length polymorphism

coexistence of wild-type and mutated alleles) was found when the resistant isolates of $C$. cassiicola, M. nattrassii, and Colletotrichum gloeosporioides (strawberry anthracnose fungus) were subcultured in the presence or absence of QoI fungicides. QoI resistance of cucumber powdery and downy mildew isolates persisted for a few years following the removal of the selection pressure imposed by the fungicide under both laboratory and commercial greenhouse conditions. The proportion of mutated sequences in cytochrome $b$ gene decreased over time in the pathogen population. The protective efficacy of the full dose of azoxystrobin decreased when the populations of powdery and downy mildews contained resistant isolates at $10 \%$. Using FMBIO, a fluorescence bioimaging analyzer, the mutant allele from the QoI-resistant isolates could be detected at the level of $1 \%$, whereas the detection sensitivity of ethidium-bromide-stained gels was $\approx 10$ times lower.
\end{abstract} commonly used for QoI resistance monitoring were employed successfully, leading to the amplified gene fragment from resistant isolates being cut with the restriction enzyme ItaI. However, heteroplasmy (the
Additional keywords: mitochondrial DNA, point mutation.
QoI fungicides (inhibitors of mitochondrial respiration at QoI site of cytochrome $b c l$ enzyme complex), including strobilurins such as azoxystrobin and kresoxim-methyl, represent one of the most important classes of agricultural fungicides, with azoxystrobin being the world's largest-selling fungicide $(3,34)$. However, it is also well known that QoI fungicides have a high risk of resistance development in their target pathogens (14). For example, between 1998 and 2000, shortly after the introduction of these fungicides, control failures of powdery mildew (Podosphaera xanthii $=$ Sphaerotheca fusca) or downy mildew (Pseudoperonospora cubensis) first were reported on cucumber in Taiwan, Japan, and Spain $(15,19)$. Subsequently, QoI resistance in Japan also has occurred in eggplant leaf mold (Mycovellosiella nattrassii), cucumber Corynespora leaf spot (Corynespora cassiicola), and strawberry anthracnose (Colletotrichum gloeosporioides) $(6,16,33)$. QoI resistance has now been reported in at least 20 pathogens, including wheat powdery mildew, grapevine downy mildew, apple scab, and others in Asia, Europe, and North America $(14,18,26)$.

In many cucumber greenhouses in Japan where the efficacy of QoI fungicides was lost against powdery and downy mildews, use of these fungicides is restricted. Despite this, resistant isolates are still widely distributed in both pathogen populations 2 years after product withdrawal. This indicates that resistant isolates do not

Corresponding author: H. Ishii; E-mail address: hideo@niaes.affrc.go.jp

doi:10.1094/PHYTO-97-11-1458

(C) 2007 The American Phytopathological Society necessarily possess a fitness penalty caused by the absence of the selection pressure from these fungicides (20).

Ishii et al. (19) elucidated the molecular mechanism of QoI resistance in cucumber powdery and downy mildews. The resistance mechanism is based on a single point mutation found in the mitochondrial cytochrome $b$ gene, and molecular diagnostic methods were developed to successfully identify resistant isolates of both pathogens (20). A partial fragment of the cytochrome $b$ gene was amplified using polymerase chain reaction (PCR). The PCR product then was treated using a mutation-specific restriction enzyme ItaI $(=F n u 4 \mathrm{HI})$. The PCR products from resistant isolates carrying the mutated sequence $\mathrm{GCN}$ at position 143 could be digested by the restriction enzyme, whereas those from sensitive isolates remained undigested. This PCR-restriction fragment length polymorphism (RFLP) technique also has been used successfully to identify QoI resistance in a range of other fungal plant pathogens, such as Blumeria graminis f. sp. tritici (wheat powdery mildew), Mycosphaerella fijiensis (black Sigatoka of banana), Alternaria alternata (Alternaria late blight in pistachio), and Pyricularia grisea (gray leaf spot of perennial ryegrass) $(4,21,24,29,30)$.

The QoI-targeted cytochrome $b$ protein is encoded by mitochondrial DNA (mtDNA); this DNA generally is thought to mutate at a higher frequency than that of nuclear DNA $(5,28)$. This genetic trait must have greatly influenced the rapid development of resistance to QoI fungicides. However, the story of QoI resistance seems to be more complicated due to the heteroplasmic as well as homoplasmic status of mtDNA (14). In the former case, mutated DNAs are concomitant with wild-type normal DNAs in 
an individual mitochondrion where large numbers of multicopy DNAs exist. Therefore, it is interesting and important to know what ratio of mutated mitochondrial cytochrome $b$ gene in fungal cells is required to result in a resistant phenotype.

Major objectives of this study were to (i) characterize the molecular mechanism of QoI resistance in eggplant leaf mold and cucumber Corynespora leaf spot pathogens; (ii) examine whether the molecular method PCR-RFLP also could be applied for the diagnosis of QoI resistance in these two pathogens; (iii) further monitor the stability of mutated cytochrome $b$ gene in cucumber powdery and downy mildews when selection pressure by QoI fungicides is removed in the laboratory or in the field; (iv) know the relationship between the ratio of the resistant and sensitive fungal populations with decreased efficacy of QoI fungicides; and, finally, (v) develop a highly sensitive method to detect mutated cytochrome $b$ genes.

\section{MATERIALS AND METHODS}

Fungicides and pathogen isolates. Commercial formulation of azoxystrobin (20\% flowable) was used. The isolates used in this work are listed on Table 1. Single-spore isolates of Mycovellosiella nattrassii were obtained from eggplant grown in greenhouses located in Kochi Prefecture, Japan. Isolates of Corynespora cassiicola were from cucumber greenhouses in Ibaraki, Okayama, and Saga Prefectures, Japan. Additionally, two isolates of the C. cassiicola originally from Oita Prefecture, Japan, also were used as sensitive references. The isolates of Colletotrichum gloeosporioides NM-1 and GC-2 and the C. acutatum isolates Na91016 and G5-1 7 (both gifts from Tochigi Prefectural Agricultural Experiment Station and Akita Fruit Tree Experiment Station) were obtained from anthracnose-infected strawberry or grapevine plants. All the isolates were maintained on potato dextrose agar (PDA) (Difco Laboratories, Detroit) slants and stored at $5^{\circ} \mathrm{C}$ until use.

Isolates of cucumber powdery mildew R-2, S-1, S-3 (all resistant to QoI fungicides; mass-spore isolates from Ibaraki) (19), and K-7-2 (sensitive to QoIs; provided by ZEN-NOH Agricultural Research and Development Center, Japan) were used to inoculate, by using a sterile swab, detached healthy leaves of cucumber (cv. Shin Suyo Tsukemidori) kept on a moist filter paper placed in a sterile plastic petri dish. They then were kept at $20^{\circ} \mathrm{C}$ under fluorescent light at 12 -h intervals and the subinoculation was repeated every 10 days in the laboratory for approximately 3.5 years, starting in May 1999.

Cucumber downy mildew isolate A1-10 was obtained from a mass of zoosporangia at a greenhouse in Ibaraki in January 2000 and maintained in the laboratory for approximately three-and-ahalf years. Subinoculation has been repeated every 10 days using detached healthy cucumber leaves in the same manner as described for powdery mildew, except that a sterile paint brush and a glass petri dish were used for collecting zoosporangia from lesions used to inoculate leaves and for incubating inoculated leaves in it, respectively.

A commercial cucumber greenhouse at Akeno, Ibaraki in which QoI-resistant populations of powdery and downy mildew pathogens frequently had been detected was chosen. As reported earlier (20), resistant isolates of these two pathogens were still present at a high level in the greenhouse 2 years after the withdrawal of QoI fungicides to control these diseases. Two-and-a-half years after the withdrawal, isolates of powdery and downy mildew were collected from the greenhouse and their sensitivities to azoxystrobin were determined by the in vivo methods described below. PCRRFLP analysis of the cytochrome $b$ gene also was conducted using total DNA extracted from downy mildewed leaf disks as mentioned before (20).

In vitro fungicide sensitivity tests. Isolates of Corynespora cassiicola, Colletotrichum gloeosporioides, C. acutatum, and $M$. nattrassii were precultured on PDA plates at $25^{\circ} \mathrm{C}$ in the dark for 5 days, with the exception of $M$. nattrassii, which was precultured for 45 days. Mycelial disks ( $4 \mathrm{~mm}$ in diameter) were cut from the outer edge of each colony and transferred to fresh PDA plates supplemented with azoxystrobin at $0,1,10$, and $100 \mu \mathrm{g}$ a.i. $\mathrm{ml}^{-1}$. The colony diameter then was measured after 3 days for Corynespora cassiicola, Colletotrichum gloeosporioides, and C. acutatum and after 21 days for $M$. nattrassii, after incubation in the dark at $25^{\circ} \mathrm{C}$. The percent growth inhibition then was calculated using the formula ([colony diameter on fungicide-free medium $-4 \mathrm{~mm}$ ] [colony diameter on azoxystrobin-amended medium $-4 \mathrm{~mm}$ ])/ (colony diameter on fungicide-free medium $-4 \mathrm{~mm}$ ) $\times 100$.

For Corynespora cassiicola and $M$. nattrassii, two azoxystrobin-resistant isolates previously known to carry the point mutation (GGT to GCT) and two azoxystrobin-sensitive isolates containing the wild-type gene encoding the cytochrome $b$ at codon 143 were chosen for the experiment. A field mutant isolate of Colletotrichum gloeosporioides and a wild-type isolate of $C$. acutatum also were used. To examine the changes over time in the proportions of the mutated DNA, subculturing of Corynespora cassiicola, Colletotrichum gloeosporioides, and C. acutatum was carried out every week for a total of 40 times, while $M$. nattrassii was subcultured every 45 days for a total of 25 times. At each subculture, the isolates were inoculated on PDA plates containing azoxystrobin at $100 \mu \mathrm{g}$ a.i. $\mathrm{ml}^{-1}$ and PDA control plates containing no fungicide. After subculturing every 5 or 10 times, the total DNA was extracted from mycelia formed on the culture medium, the cytochrome $b$ gene fragment was PCR amplified, and the PCR product then was treated with the restriction enzyme ItaI. Additionally, for M. nattrassii following each subculturing, the mycelial growth of each isolate was measured and changes in their sensitivities to azoxystrobin were recorded.

In vivo fungicide sensitivity tests. Cucumber Corynespora leaf spot. Whole leaves of 4-week-old potted cucumber plants (cv. Shin Suyo Tsukemidori or High Green 22), grown at $25^{\circ} \mathrm{C}$ in a

TABLE 1. Source of fungal isolates used in this study

\begin{tabular}{|c|c|c|}
\hline Species, host & Isolate & Location \\
\hline \multicolumn{3}{|c|}{ Mycovellosiella nattrassii } \\
\hline Eggplant & $\mathrm{T}-1^{\mathrm{a}}$ & Kochi \\
\hline Eggplant & $\mathrm{M}-4^{\mathrm{a}}$ & Kochi \\
\hline Eggplant & $\mathrm{T}-5^{\mathrm{a}}$ & Kochi \\
\hline Eggplant & $\mathrm{K}-1^{\mathrm{a}}$ & Kochi \\
\hline \multicolumn{3}{|c|}{ Corynespora cassiicola } \\
\hline Cucumber & AKE 3-2 & Ibaraki \\
\hline Cucumber & AKE 3-3 & Ibaraki \\
\hline Cucumber & SHIMO 1-7-1 & Ibaraki \\
\hline Cucumber & SHIMO 1-7-2 & Ibaraki \\
\hline Cucumber & SHIMO 1-7-3 & Ibaraki \\
\hline Cucumber & ST-1S-1 ${ }^{\mathrm{b}}$ & Okayama \\
\hline Cucumber & ST-20S- $1^{b}$ & Okayama \\
\hline Cucumber & $\mathrm{C} 2-6$ & Saga \\
\hline Cucumber & C6-2 & Saga \\
\hline Cucumber & C95473-1 & Oita \\
\hline Cucumber & C95473-3 & Oita \\
\hline \multicolumn{3}{|c|}{ Colletotrichum gloeosporioides } \\
\hline Strawberry & NM-1 & Tochigi \\
\hline Grapevine & GC-2 & Akita \\
\hline \multicolumn{3}{|l|}{ C. acutatum } \\
\hline Strawberry & Na91-016 & Tochigi \\
\hline Grapevine & G5-1 7 & Akita \\
\hline \multicolumn{3}{|c|}{ Podosphaera xanthii } \\
\hline Cucumber & $\mathrm{K}-7-2^{\mathrm{c}}$ & Kanagawa \\
\hline Cucumber & $\mathrm{R}-2^{\mathrm{c}}$ & Ibaraki \\
\hline Cucumber & $\mathrm{S}-1^{\mathrm{c}}$ & Ibaraki \\
\hline Cucumber & $S-3^{c}$ & Ibaraki \\
\hline \multicolumn{3}{|c|}{ Pseudoperonospora cubensis } \\
\hline Cucumber & A $1-10$ & Ibaraki \\
\hline
\end{tabular}

a Published by Yano and Kawada (33).

${ }^{b}$ Published by Date et al. (6).

c Published by Ishii et al. (19). 
phytotron, were sprayed with a diluted commercial formulation of azoxystrobin at $100 \mu \mathrm{g}$ a.i. $\mathrm{ml}^{-1}$, the recommended concentration for commercial use. Distilled water (DW) was used as a control. Two or three replicate plants also were prepared for each treatment. After air drying, the plants were inoculated by spraying conidial suspensions $\left(\approx 1 \times 10^{5}\right.$ conidia $\left.\mathrm{ml}^{-1}\right)$ of the pathogen, stored at $25^{\circ} \mathrm{C}$ in a dew chamber for $36 \mathrm{~h}$, and then maintained at $25^{\circ} \mathrm{C}$ in a phytotron. Disease development on each leaf was recorded 7 days after inoculation using the following scale: $0=$ no visible symptoms, $0.1=<1,0.5=1$ to $5,1=6$ to $10,2=11$ to 20 , $3=21$ to $30,4=31$ to $40,5=41$ to $50,6=51$ to $60,7=61$ to 70 , $8=71$ to $80,9=81$ to 90 , and $10=>91 \%$ of leaf area diseased. Disease severity (DS) was calculated as $([10 A+9 B+8 C+7 D+$ $6 E+5 F+4 G+3 H+2 I+1 J+0.5 K+0.1 L] / 10 M) \times 100$, where $A, B, C, D, E, F, G, H, I, J, K$, and $L$ are the number of leaves corresponding to the scales $10,9,8,7,6,5,4,3,2,1,0.5$ and 0.1 , respectively, and $M$ is the total number of leaves assessed.

Cucumber powdery mildew and downy mildew. Sensitivity of isolates to azoxystrobin was determined by leaf disk or foliar spray tests according to the methods previously described in Ishii et al. (19). In mixed inoculation tests, spore suspensions $\left(\approx 1 \times 10^{5}\right.$ conidia $\mathrm{ml}^{-1}$ ) prepared from QoI-resistant and -sensitive isolates were mixed in 1:0, 9:1, 1:1, 1:9.1:99, and 0:1 ratios, then sprayed onto leaves of potted cucumber plants pretreated with azoxystrobin at $100 \mu \mathrm{g}$ a.i. $\mathrm{ml}^{-1}$.

Isolation of total DNA. Isolates of Corynespora cassiicola, Colletotrichum gloeosporioides, and C. acutatum were cultured on PDA plates at $25^{\circ} \mathrm{C}$ in the dark for 5 days and $M$. nattrassii was cultured similarly for 45 days. Aerial mycelia formed on a colony were collected with a stainless spatula, lyophilized, and ground with a mortar and pestle using glass beads. Total DNA then was extracted and purified using the DNeasy Plant Mini Kit (Qiagen, Hilden, Germany) according to the manufacturer's instructions. For cucumber powdery and downy mildews, disks of $1 \mathrm{~cm}$ in diameter were cut from cucumber leaves bearing conidia or zoosporangia, respectively, and used for DNA purification with the method mentioned above, except that liquid nitrogen was employed when grinding fresh material.

PCR experiments. To amplify pathogen cytochrome $b$ gene fragments from total DNA, the following PCR primers $(11,19)$ were used: RSCBF1, 5'-TATTATGAGAGATGTAAATAATGG-3' and RSCBR2, 5'-AACAATATCTTGTCCAATTCATGG-3'. PCR reaction mixtures contained total DNA, $1.5 \mathrm{mM} \mathrm{MgCl} 2,200 \mu \mathrm{M}$ each dNTP, and 2.5 units of Taq DNA polymerase (Nippon Gene, Toyama, Japan). PCR reactions were performed in a Program Temperature Control System PC707-05 (ASTEC, Fukuoka, Japan) programmed for $2.5 \mathrm{~min}$ at $94^{\circ} \mathrm{C}$, followed by 40 cycles of $0.5 \mathrm{~min}$ at $94^{\circ} \mathrm{C}, 1 \mathrm{~min}$ at $52^{\circ} \mathrm{C}, 1.5 \mathrm{~min}$ at $72^{\circ} \mathrm{C}$, a final extension for $8.5 \mathrm{~min}$ at $72^{\circ} \mathrm{C}$, and holding at $4^{\circ} \mathrm{C}$. PCR products were separated by electrophoresis on a $1.5 \%$ agarose gel in $40 \mathrm{mM}$ Trisacetate (pH 8.0) and $1 \mathrm{mM}$ EDTA (TAE) buffer and stained with ethidium bromide.

Direct sequencing of DNA. PCR products were purified using either MicroSpin S-400HR columns (Amersham Pharmacia Biotech Inc., Piscataway, NJ) or Wizard SV Gel and PCR Clean-Up System (Promega Corp., Madison, WI) according to the instructions supplied by the manufacturers. Purified PCR products were sequenced with the automated DNA sequencer Prism Model (Applied Biosystems, Foster City, CA) by using fluorescent-dyelabeled dideoxy terminators. After sequencing, the nucleotide sequences were translated to amino acid sequences with National Center for Biotechnology Information or GenBank yeast mitochondrial code.

Diagnosis and monitoring of resistance by PCR-RFLP. As reported previously $(19,20)$, in QoI-resistant isolates of Pseudoperonospora cubensis, one base-change from guanine to cytosine occurred at amino acid codon 143, resulting in the substitution of glycine with alanine of the targeted cytochrome $b$ protein. In the current work, the same point mutation was found in the sequence of the cytochrome $b$ gene in QoI-resistant isolates of both Corynespora cassiicola and M. nattrassii (Fig. 1). Furthermore, the isolate of Colletotrichum gloeosporioides NM-1 also was shown to possess this mutation. This point mutation is recognized by the restriction enzyme ItaI $(=F n u 4 \mathrm{HI})$ having the recognition sequences 5'-GCNGC-3', as in the case of $P$. cubensis (20).

Fragments of the cytochrome $b$ gene, PCR amplified from the total DNA of QoI-resistant and -sensitive isolates, were treated with the enzyme ItaI (Roche Diagnosis, Mannheim, Germany) according to the manufacturer's protocol. Digests were run on a $2 \%$ agarose gel with TAE buffer and stained with ethidium bromide.

Highly sensitive methods for detecting mutated cytochrome $b$ gene using FMBIO. PCR-amplified fragments of the cytochrome $b$ gene derived from QoI-resistant and -sensitive isolates of cucumber downy mildew were purified, ligated into pGEMEasy vectors (Promega), and transformed into competent $E s$ cherichia coli (JM109) cells in accordance with the manufacturer's instructions.

Two plasmid clones which contained the mutant-type and wildtype cytochrome $b$ gene, respectively, were quantified spectrophotometrically and mixed in a range of ratios (i.e., 0:100, 1:99, 10:90, 50:50, and 100:0) to be used for PCR amplification of the cytochrome $b$ gene fragment. PCR was performed in the same manner as mentioned above but using primer set RSCBF1 and RSCBR2-Rho ( $3^{\prime}$ end of RSCBR2 labeled with a fluorescent-dye rhodamine). The PCR products then were treated with the ItaI (Roche Diagnosis) according to the manufacturer's protocol and the products run on an $8 \%(\mathrm{wt} / \mathrm{vol})$ capillary polyacrylamide gel for $40 \mathrm{~min}$ at $20 \mathrm{~mA} / \mathrm{gel}$ followed by analysis using a fluorescence bio-imaging analyzer FMBIO 100 (Hitachi Software Engineering Co. Ltd., Tokyo).

When PCR products contained the mutant-type cytochrome $b$ gene, ItaI treatment of the products resulted in the formation of both 245- and 40-bp fragments on a gel. Integrated optical density (IOD) of each band was measured by FMBIO and the proportion of mutant-type cytochrome $b$ gene calculated by the following formula: value of IOD (40-bp fragment)/(value of IOD [245-bp fragment] + value of IOD [40-bp fragment] $) \times 100$. The principle and method of this analysis are illustrated in Figure 2. A control also was performed using the same samples, but with the use of a nonfluorescence-labeled reverse primer (RSCBR2), following ItaI enzyme treatment. The treated PCR products were run on a $1.5 \%$ agarose gel stained with ethidium bromide.

\section{RESULTS}

In vitro fungicide sensitivity of pathogenic fungi. Sensitivities of fungal isolates to commercial formulations of azoxystrobin were examined based on mycelial growth on fungicideamended PDA plates. Two isolates of $M$. nattrassii (the cause of eggplant leaf mold), T-1 and M-4, were sensitive to azoxystrobin, and a strong inhibition of growth was observed as low as $1 \mu \mathrm{g}$ a.i. $\mathrm{ml}^{-1}$ (Table 2). However, two other isolates, T-5 and K-1, were highly resistant and grew even in the presence of the fungicide at $100 \mu \mathrm{g} \mathrm{ml}^{-1}$. Isolates of Corynespora cassiicola (Corynespora leaf spot fungus), Colletotrichum gloeosporioides, and C. acutatum all showed low inherent sensitivity to azoxystrobin using this in vitro testing method (Table 2).

In vivo fungicide tests: detection of QoI-resistant isolates in cucumber Corynespora leaf spot fungus. A foliar pathogen inoculation test was carried out using potted cucumber plants which were pretreated with fungicide. Azoxystrobin at $100 \mu \mathrm{g} \mathrm{ml}^{-1}$ showed complete control against two single-spore isolates, C95473-1 and C95473-3 (Table 3). In contrast, the efficacy against five other isolates (AKE-3-2, AKE-3-3, SHIMO 1-7-1, SHIMO 1-7-2, and SHIMO 1-7-3) was lower, suggesting that 
QoI-resistant isolates had emerged in the commercial cucumber greenhouses. In fact, isolates of cucumber powdery mildew and downy mildew resistant to QoI fungicides already had been detected from the greenhouse where sampling of Corynespora leaf spot fungus was performed. Two isolates ST-1S-1 and ST-20S-1 exhibited a very high resistance to azoxystrobin on cucumber plants previously sprayed with this fungicide at the manufacturers' recommended rates; however, isolates C2-6 and C6-2 remained sensitive (Table 3 ).

PCR amplification and sequence analysis of cytochrome $b$ gene. A single fragment, of $\approx 285 \mathrm{bp}$ in size, was produced with the use of primers RSCBF1 and RSCBR2, using total DNA from both cucumber Corynespora leaf spot fungus and eggplant leaf mold isolates. The amplified products were purified and sequenced directly. The partial sequence of nucleotide and the deduced amino acid of the cytochrome $b$ from both QoI-resistant and -sensitive isolates are shown in Figure 1. The nucleotide sequence at codon 143 was confirmed as GGT or GGA coding for the amino acid glycine in four sensitive isolates of Corynespora cassiicola and two sensitive isolates of $M$. nattrassii. However, the sequence was different in four resistant isolates of $C$. cassiicola and two resistant isolates of $M$. nattrassii, changing to GCT or GCA at codon 143 coding for the amino acid alanine. Furthermore, one stock isolate (NM-1) of Colletotrichum gloeosporioides also revealed the same point mutation at codon 143.

PCR-RFLP. PCR products were treated with the restriction enzyme ItaI $(=F n u 4 \mathrm{HI})$ and analyzed on agarose gels. Products from two resistant isolates of Corynespora cassiicola (ST-1S-1 and ST-20S-1) and two resistant isolates of $M$. nattrassii (T-5 and $\mathrm{K}-1$ ) all were cut by the enzyme, resulting in the formation of two bands. The products from the sensitive isolates of the two fungal species (C. cassiicola $\mathrm{C} 2-6$ and C6-2; $M$. nattrassii $\mathrm{T}-1$ and $\mathrm{M}-4)$ were never digested following enzyme treatment. Six other singlespore isolates of $C$. cassiicola shown in Table 1 (except for
C95473-3) also were tested using PCR-RFLP analysis. PCR products from the sensitive isolate C95473-1 were not cut following ItaI enzyme treatment. Although a positive control of mutated cytochrome $b$ gene was clearly cut, PCR products from other isolates of C. cassiicola tested were digested only slightly by ItaI treatment (i.e., undigested and digested bands appeared concomitantly on a gel, suggesting that the mutated and wild-type cytochrome $b$ genes coexisted in multiple copies in the mtDNA of these isolates). PCR products from the isolate NM-1 (Colletotrichum gloeosporioides) also were digested with ItaI, whereas those from the isolate Na91-016 (C. acutatum) were not digested.

Persistence of QoI resistance and mutated cytochrome $b$ gene sequences in a laboratory. Cucumber powdery mildew. Three QoI-resistant (R-2, S-1, and S-3) and one QoI-sensitive (K7-2) isolates of this pathogen were inoculated successively on fungicide-untreated fresh cucumber leaves. Three-and-a-half

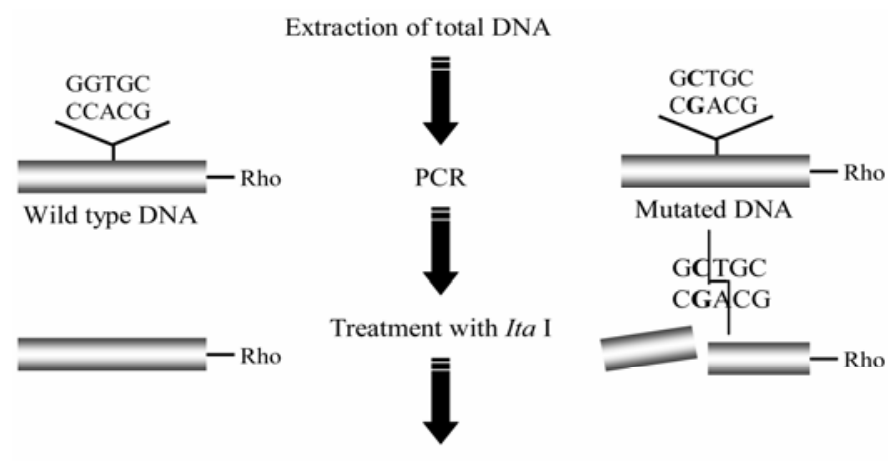

Polyacrylamide gel electrophoresis

Detection with fluorescent image analyzer

Fig. 2. Method for analysis of mutation in cytochrome $b$ gene.

\section{C. cassiicola}

Sensitive isolate C6-2:

$$
\text { • • ggtCaAatgtcCttatga GGTGCAaCAgttattact • • • }
$$

Resistant isolate ST-20S-1:

$$
\begin{aligned}
& \text { ItaI } \\
& \text { • - ggtcaAatgtccttatga gCt gCaACAgttattact • • }
\end{aligned}
$$

\section{M. nattrassii}

Sensitive isolate T-1:

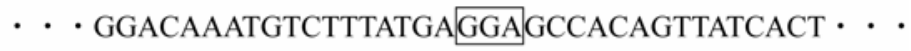

Resistant isolate K-1:

$$
\begin{aligned}
& \text { ItaI }
\end{aligned}
$$

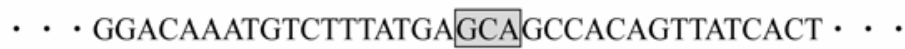

$\begin{array}{ll}\text { C. cassiicola } & \text { C6-2: } \\ & \text { ST-20S-1: } \\ \text { M. nattrassii } & \text { T-1: } \\ & \text { K-1: }\end{array}$

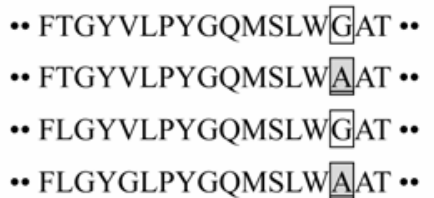

Fig. 1. Partial nucleotide sequences of cytochrome $b$ gene, restriction site of the enzyme ItaI, and deduced amino acid of the protein in QoI-resistant and -sensitive isolates of Corynespora cassiicola and Mycovellosiella nattrassii. 
years after the onset of subinoculations, a high level of the resistance to the fungicide azoxystrobin still was maintained in resistant isolates (Table 4). However, results from the ItaI digestion experiment exhibited a decrease of the proportion of mutated cytochrome $b$ gene and an increase of wild-type DNA following repeated subinoculation in the absence of the selection pressure by QoI fungicides (Fig. 3). Only a small proportion of the PCR product was cut using ItaI and most of the DNA remained as the wild type (undigested with ItaI). To further confirm the results from the PCR-RFLP experiment, the nucleotide sequence from individual isolates was analyzed. In all resistant isolates used, after successive subinoculation, the mutated DNA sequence at the codon 143 had converted from GCT to GGT, which is the typical sequence of wild-type DNA. The sequence in sensitive isolates never changed and possessed GGT at the codon 143 in the cytochrome $b$ gene during this subinoculation experiment. The sequencing experiment was repeated twice, confirming the same results in both resistant and sensitive isolates.

In the resistant isolate of Corynespora cassiicola AKE-3-2, the mutated DNA sequence was not detected when it had been subcultured a total of five times on fungicide-free medium (Table 5). In contrast, the isolate continued to carry the point mutation up to the 10th successive subculture onto azoxystrobin-amended medium. In the Colletotrichum gloeosporioides isolate NM-1, which possessed the mutated DNA sequence, the mutation sequence disappeared more rapidly than Corynespora cassiicola, regardless of the presence or absence of fungicides in subculture medium. Mutated DNA sequence was not recognized after subculturing 10 times in the presence and absence of azoxystrobin. For the slowgrowing fungus $M$. nattrassii, the mutated DNA sequence was present until the 25th subculture in both azoxystrobin-amended and unamended medium. In all sensitive isolates of the three pathogens, digestion of the PCR products by ItaI was never detected.

When the resistant isolate of $M$. nattrassii (T-5) was subcultured repeatedly on azoxystrobin-amended and unamended medium, inhibition of mycelial growth by azoxystrobin tended to decrease. After subculturing 25 times, growth inhibition (\%) of azoxystrobin at $10 \mu \mathrm{g}$ a.i. $\mathrm{ml}^{-1}$ against the isolate decreased from 39.4 to 1.4 and from 46.2 to 22.4 in the presence or absence of

TABLE 2. Mycelial growth of fungal isolates on azoxystrobin-amended potato dextrose agar medium ${ }^{\mathrm{a}}$

\begin{tabular}{|c|c|c|c|}
\hline \multirow[b]{2}{*}{ Species, isolate } & \multicolumn{3}{|c|}{ Growth inhibition (\%) of azoxystrobin at } \\
\hline & $1 \mu \mathrm{g} \mathrm{ml}^{-1}$ & $10 \mu \mathrm{g} \mathrm{ml}^{-1}$ & $100 \mu \mathrm{g} \mathrm{ml}^{-1}$ \\
\hline \multicolumn{4}{|c|}{ Mycovellosiella nattrassii } \\
\hline $\mathrm{T}-1$ & 94.4 & 100 & 100 \\
\hline M-4 & 70.9 & 100 & 100 \\
\hline $\mathrm{T}-5$ & 5.3 & 45.3 & 36.7 \\
\hline $\mathrm{K}-1$ & 9.1 & 51.9 & 48.1 \\
\hline \multicolumn{4}{|c|}{ Corynespora cassiicola } \\
\hline AKE 3-2 & 21.7 & NT & 30.7 \\
\hline AKE 3-3 & 13.7 & NT & 40.3 \\
\hline SHIMO 1-7-1 & 10.4 & NT & 31.3 \\
\hline SHIMO 1-7-2 & 42.9 & NT & 46.2 \\
\hline SHIMO 1-7-3 & 41.5 & NT & 64.1 \\
\hline ST-1S-1 & 12.6 & 29.2 & 8.2 \\
\hline ST-20S-1 & 12.2 & 26.4 & 27.6 \\
\hline $\mathrm{C} 2-6$ & 29.2 & 29.0 & 31.7 \\
\hline C6-2 & 31.4 & 32.0 & 31.2 \\
\hline C95473-1 & 36.4 & NT & 49.4 \\
\hline C95473-3 & 48.6 & NT & 48.9 \\
\hline \multicolumn{4}{|c|}{ Colletotrichum gloeosporioides } \\
\hline NM-1 & 25.9 & 28.4 & 27.3 \\
\hline GC-2 & 33.8 & 30.9 & 31.2 \\
\hline \multicolumn{4}{|l|}{ C. acutatum } \\
\hline Na91-016 & 43.8 & 54.5 & 57.8 \\
\hline G5-1 7 & 84.5 & 93.0 & 95.2 \\
\hline
\end{tabular}

${ }^{a} \mathrm{NT}=$ not tested. this fungicide, respectively. However, azoxystrobin sensitivity did not change remarkably in isolate $\mathrm{K}-1$, changing from 37.4 to 31.1 and from 42.1 to 39.9 in the presence or absence of this fungicide, respectively. Inhibitory activity of the fungicide against sensitive isolates also decreased when they were continuously grown on azoxystrobin-amended medium. The percent inhibition of azoxystrobin at $10 \mu \mathrm{g}$ a.i. $\mathrm{ml}^{-1}$ against isolates $\mathrm{T}-1$ and $\mathrm{M}-4$ changed from 100 to $5.2 \%$ and from 100 to $-15.6 \%$, respectively, after 25 times subculturing on azoxystrobin-amended medium. In contrast, the growth of these sensitive isolates always was inhibited completely by azoxystrobin at $10 \mu \mathrm{g} \mathrm{ml}^{-1}$ when they were subcultured in the absence of fungicide (data not shown).

Persistence and decline of fungal isolates carrying the mutated cytochrome $b$ gene under greenhouse conditions. In a commercial cucumber greenhouse at Ibaraki in which QoI-resistant populations of powdery and downy mildew pathogens still had been detected at a high level 2 years after the withdrawal of QoI fungicides, azoxystrobin-resistant isolates of powdery mildew were not detected two-and-a-half years after the withdrawal. In contrast, all isolates of downy mildew tested at this time were found to be resistant to azoxystrobin in planta. Interestingly, the results of the PCR-RFLP analysis revealed that the proportion of mutated DNA decreased, whereas wild-type DNA had recovered. The PCR products of cytochrome $b$ gene were digested only slightly by the treatment with ItaI.

Threshold of the resistant fungal populations in relation to fungicide efficacy. Product performance of the full rate of azoxystrobin for the control of cucumber powdery mildew decreased by $\approx 50 \%$ when an inoculum source contained resistant populations at a level of $10 \%$ (Table 6). Similar results were obtained with downy mildew and Corynespora leaf spot. Control of azoxystrobin at $10 \mu \mathrm{g}$ a.i. $\mathrm{ml}^{-1}$ against downy mildew was $100,66.7$, $20.0,-6.7$, and 0 when resistant conidia were included in ratios of $0,1,10,50$, and $100 \%$ in the inoculum of bioassays. The control was $83.3,86.8,85.1,47.1,10.8$, and -40.6 when the inoculum contained resistant conidia of $C$. cassiicola in ratios of $0,1,5,10$, 50 , and $100 \%$, respectively.

The influence of inoculum density on the efficacy of the fungicide was examined further using the powdery mildew fungus containing resistant and sensitive populations at a ratio of 1:9. As predicted, disease control at labeled rates of azoxystrobin was less effective when the density was higher: 23.3 at $1 \times 10^{5}{\text { conidia } \mathrm{ml}^{-1}}^{-1}$ and 50.0 at $1 \times 10^{4}$ conidia $\mathrm{ml}^{-1}$.

Highly sensitive methods for the detection of mutated cytochrome $\boldsymbol{b}$ genes using FMBIO. Cloned cytochrome $b$ gene fragments derived from a QoI-resistant and -sensitive isolate of cucumber downy mildew were mixed in various ratios (i.e.,

TABLE 3. Efficacy of azoxystrobin against Corynespora leaf spot disease of cucumber inoculated with various isolates of Corynespora cassiicola

\begin{tabular}{lcc}
\hline & \multicolumn{2}{c}{ Disease severity $^{\mathrm{a}}$} \\
\cline { 2 - 3 } Isolate & $0.0^{* *}$ & Distilled water \\
\hline C95473-1 & $0.0^{* *}$ & 22.2 \\
C95473-3 & $17.8^{* *}$ & 22.2 \\
AKE-3-2 & $17.8^{* *}$ & 42.2 \\
AKE-3-3 & $20.0^{* *}$ & 57.8 \\
SHIMO 1-7-1 & $26.7 * *$ & 57.8 \\
SHIMO 1-7-2 & $33.3^{* *}$ & 64.4 \\
SHIMO 1-7-3 & 27.8 & 77.8 \\
ST-1S-1 & 36.3 & 27.5 \\
ST-20S-1 & $0.8^{* *}$ & 38.8 \\
C2-6 & $1.7 * *$ & 12.5 \\
C6-2 & & 31.3 \\
\hline a Disease severity was calculated as $([10 A+9 B+8 C+7 D+6 E+5 F+4 G+$ \\
$3 H+2 I+1 J+0.5 K+0.1 L] / 10 M) \times 100$, where $A, B, C, D, E, F, G, H, I, J$, \\
$K$, and $L$ are the number of leaves corresponding to the scales, $10,9,8,7,6$, \\
$5,4,3,2,1,0.5$ and 0.1, respectively, and $M$ is the total number of leaves \\
assessed; $* *$ indicates $P$ value of $<0.01(t$ test).
\end{tabular}


0:100, 1:99, 10:90, 50:50, and 100:0) and PCR amplified, followed by treatment with the enzyme ItaI. Positive PCR-product bands were obtained from all combinations; however, their digestion with the enzyme was recognized only at 10:90, 50:50, and 100:0 ratios when visualized with UV on agarose gel stained with ethidium bromide. In contrast, when FMBIO analysis was used, enzyme digestion was improved, enabling detection of PCR products at 1:99, 10:90, 50:50, and 100:0. The proportion of mutated DNA detected by this method was $0.3,10,32$, and $100 \%$, respectively (data not shown).

\section{DISCUSSION}

In Japan, QoI fungicides are no longer used for the control of powdery and downy mildews in the majority of cucumber greenhouses, because resistant isolates cannot be controlled. However, these fungicides still have been used in some regions for the control of the third most important cucumber disease, Corynespora leaf spot, because the pathogen causing this disease showed resistance to other fungicides such as benzimidazoles. Isolates of M. nattrassii (eggplant leaf mold) resistant to certain sterol demethylation inhibitors are widespread (32) and, therefore, QoI fungicides were widely used as an important alternative to control this disease. As a result, QoI resistance now has also become a problem in Corynespora cassiicola and M. nattrassii.

The mycelial growth test on fungicide-amended culture medium is the method most widely used to determine fungicide sensitivity of fungal pathogens. QoI-sensitive isolates of the slowgrowing fungus $M$. nattrassii were markedly suppressed in their growth by the fungicide azoxystrobin, but resistant isolates showed reduced influence from the fungicide. However, because most other fungi, including Colletotrichum gloeosporioides and C. acutatum, are such that the growth of Corynespora cassiicola isolates was hardly inhibited by QoI fungicides on PDA plates regardless of QoI resistance or sensitivity of isolates. Sensitive isolates as well as the ones which were confirmed to be resistant on fungicide-treated plants grew well on the medium. In such cases, molecular methods can be used as a powerful tool to diagnose the resistant isolates (17).

The molecular mechanism of QoI resistance in $M$. nattrassii and Corynespora cassiicola was characterized in this study. As expected, the PCR-amplified cytochrome $b$ gene fragments showed a mutational change in the nucleotide sequence from GGT or GGA in the wild-type sensitive isolates to GCT or GCA at the amino acid position 143 in resistant isolates of both pathogens. The stock isolate NM-1 (Colletotrichum gloeosporioides) also carried the same mutation, suggesting that resistant isolates had existed before the introduction of QoI fungicides. Results from sequencing coincided with those obtained from digestion experiments using the restriction enzyme ItaI. However, some monoconidial isolates of Corynespora cassiicola appeared to carry both the mutated cytochrome $b$ gene and wild-type one concomitantly, suggesting that the gene might have been in the status of hetero- plasmy. Recently, QoI resistance of Mycosphaerella graminicola (=Septoria tritici) has become serious in the United Kingdom; however, all resistant isolates were of the homoplasmic stage in this case (9).

In the laboratory, resistant and sensitive reference isolates of powdery mildew fungus were maintained through subinoculation every 10 days for three-and-a-half years on detached healthy cucumber leaves. High azoxystrobin resistance in these isolates still remained during the whole period of this experiment. Despite this, the sequencing of a cytochrome $b$ gene fragment showed the reversion of the mutated-type sequence GCT to that of the wildtype GGT at position 143. The sensitive isolate did not alter its sensitivity to fungicide and the wild-type sequence remained GGT. This phenomenon suggests that heteroplasmy is occurring in the cytochrome $b$ gene. However, in this case, another possibility is that resistant isolates used in the experiment also might have contained small amounts of sensitive isolates from the original mass isolation of the pathogen. If so, it is also likely that resistant isolates were gradually replaced by sensitive ones due to a fitness penalty, giving rise to wild-type DNA that increased in the fungal mass. Fuji et al. (13) reported that the proportion of resistant strains of $P$. cubensis sometimes decreased over successive generations in the mixture with sensitive strains. In B. graminis f. sp. tritici, two single-spore isolates initially were found to be resistant to strobilurins but became sensitive to strobilurins after being grown for $>30$ generations without the selection pressure of fungicides (10).

To examine the stability of resistance and to confirm the existence of heteroplasmy, QoI-resistant and -sensitive isolates of

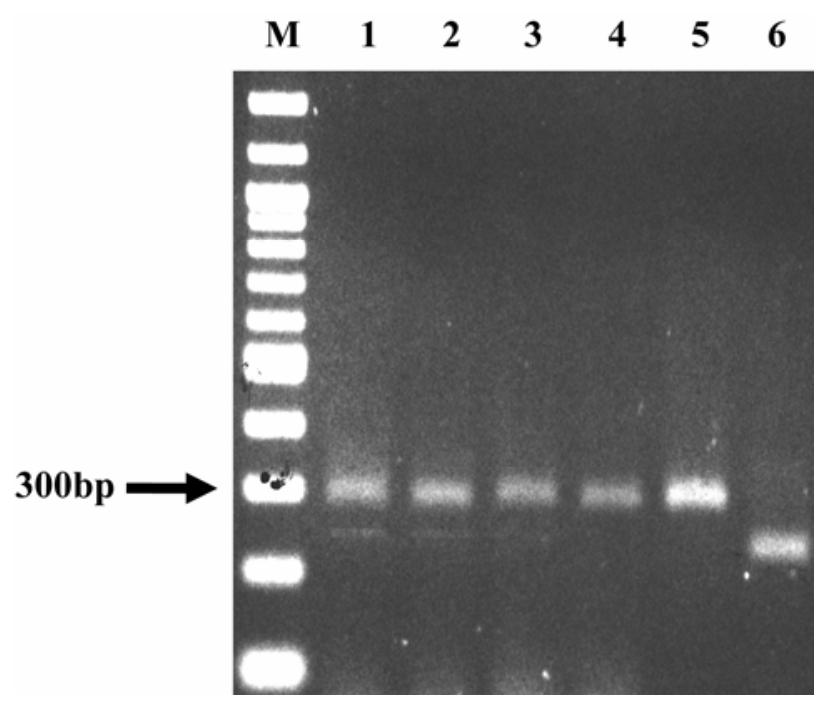

Fig. 3. ItaI digestion pattern of cytochrome $b$ gene of cucumber powdery mildew isolates after successive inoculation on untreated leaves for 3 years. M, 100-bp ladder; 1, R-2 (R); 2, S-1 (R); 3, S-3 (R); 4, K-7-2 (S); 5, negative control; 6 , positive control. Arrow indicates $300 \mathrm{bp}$.

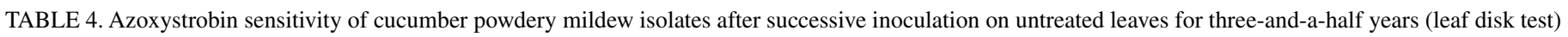

\begin{tabular}{|c|c|c|c|c|c|c|}
\hline \multirow[b]{3}{*}{ Isolate $^{\mathrm{a}}$} & \multicolumn{6}{|c|}{ Disease severity $^{b}$} \\
\hline & \multicolumn{6}{|c|}{ Concentration of azoxystrobin $\left(\mu \mathrm{g} \mathrm{ml}^{-1}\right)$} \\
\hline & 0 & 0.01 & 0.1 & 1 & 10 & 100 \\
\hline $\mathrm{R}-2(\mathrm{R})$ & 80.0 & 66.7 & 73.3 & 100 & 100 & $20.0 * *$ \\
\hline $\mathrm{S}-1(\mathrm{R})$ & 80.0 & $100^{*}$ & 73.3 & 93.3 & $6.7 * *$ & $0 * *$ \\
\hline S-3 (R) & 20.0 & 40.0 & 40.0 & $53.3 * *$ & 0 & 0 \\
\hline $\mathrm{K}-7-2(\mathrm{~S})$ & 80.0 & 0 & 0 & 0 & 0 & 0 \\
\hline
\end{tabular}

${ }^{\mathrm{a}} \mathrm{R}=$ resistant and $\mathrm{S}=$ sensitive to strobilurin fungicides.

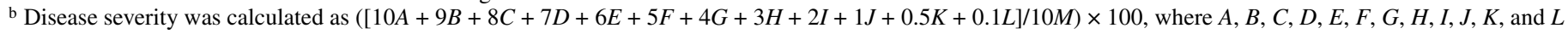

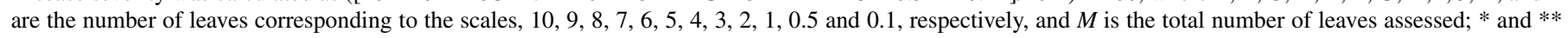
indicate $P$ value of $<0.05$ and 0.01 , respectively (Dunnet test). 
Corynespora cassiicola and Mycovellosiella nattrassii, together with an isolate of Colletotrichum gloeosporioides (all monoconidial isolates) carrying the mutated sequence in cytochrome $b$ gene, were subcultured on azoxystrobin-amended or unamended media. The mutated sequence found in the resistant isolates of Corynespora cassiicola was lost earlier in the absence of fungicide than in the presence of fungicide. Furthermore, in Colletotrichum gloeosporioides, the mutated sequence rapidly reverted to the wild-type sequence after subculturing in both the presence and absence of the fungicide. Contrasts with the fast-growing fungi were seen when compared with the slow-growing fungus $M$. nattrassii, which did not loose its mutated sequence after continuous subculturing. Differences in the speed of the reversion to wildtype sequence shown in this study may indicate the differential stability of QoI resistance in the field. In Mycosphaerella graminicola, some QoI-resistant isolates lost their resistance after subculturing and none had the G143A mutation in the cytochrome $b$ gene (27). Avila-Adame et al. (1) reported that target site mutants lacking additional amino acid exchanges may retain a heteroplasmic cytochrome $b$ population for a longer period of time and might return to a more sensitive state once the selection pressure is removed. Several factors such as metabolic activity, reproductive abilities, and the dissemination distance of the pathogen will be related to the differential stability of resistance.

Heteroplasmy of mitochondrial DNA into later developmental stages is thought to be rare in most fungi (2). However, in earlier studies, Zheng et al. (36) observed that the status of the mitochondrial cytochrome $b$ gene in laboratory mutants of Venturia inaequalis remained heteroplasmic, and mitochondria containing mutated cytochrome $b$ returned to the wild type in a high frequency during its cultivation on fungicide-unamended media. In this article, resistant isolates of Corynespora cassiicola showed a change in banding pattern following subculturing and treatment of their cytochrome $b$ gene fragments with the restriction enzyme ItaI, changing from complete to partial digestion, suggesting the heteroplasmic status of the gene. Heteroplasmy and homoplasmy states have been well documented in other organisms, particularly in medical sciences. Ling and Shibata (23) noted that mitochon-

TABLE 5. ItaI digestion of cytochrome $b$ genes amplified from cucumber Corynespora leaf spot, strawberry anthracnose, and eggplant leaf mold isolates after subculture in the presence or absence of azoxystrobin on potato dextrose agar

\begin{tabular}{llllll}
\hline & \multirow{2}{*}{$\begin{array}{c}\text { Azoxystrobin } \\
\text { in culture } \\
\text { medium }\end{array}$} & \multicolumn{3}{c}{$\begin{array}{c}\text { Digestion } \\
\text { (no. of subculture) }\end{array}$} \\
\cline { 3 - 6 } Isolate & th & 10 th & 40 th \\
\hline Corynespora cassiicola AKE-3-2 & Amended & \pm & + & - \\
Colletotrichum gloeosporioides NM-1 & None & Amended & \pm & - & - \\
& None & \pm & - & - \\
& &
\end{tabular}

a Symbols: $+=$ digested, $\pm=$ partially digested, and $-=$ not digested.

TABLE 6. Efficacy of azoxystrobin on mixed isolate populations of cucumber powdery mildew (foliar spray tests)

\begin{tabular}{lcc}
\hline & \multicolumn{2}{c}{ Disease severity $^{\mathrm{a}}$} \\
\cline { 2 - 3 } Resistant:sensitive & Azoxystrobin $100 \mu \mathrm{g} \mathrm{m}^{-1}$ & Distilled water \\
\hline $1: 0$ & 43.9 & 26.1 \\
$9: 1$ & 36.7 & 38.9 \\
$1: 1$ & 30.6 & 30.0 \\
$1: 9$ & $21.7^{*}$ & 46.7 \\
$1: 99$ & $5.0^{* *}$ & 49.4 \\
$0: 1$ & $0.0^{* *}$ & 43.3 \\
\hline
\end{tabular}

a Disease severity was calculated as $([10 A+9 B+8 C+7 D+6 E+5 F+4 G+$ $3 H+2 I+1 J+0.5 K+0.1 L] / 10 M) \times 100$, where $A, B, C, D, E, F, G, H, I, J$, $K$, and $L$ are the number of leaves corresponding to the scales, $10,9,8,7,6$, $5,4,3,2,1,0.5$, and 0.1 , respectively, and $M$ is the total number of leaves assessed; * and ** indicate $P$ value of $<0.05$ and 0.01 , respectively $(t$ test). dria carry many copies of their genome, which can be quickly segregated during mitotic growth. Consequently, all mtDNA copies are often genetically homogeneous within individuals (homoplasmic). In Saccharomyces cerevisiae, Mhr1p (a nuclear gene-encoded mtDNA-recombination protein-dependent pathway) is required for the formation of mitochondrial homoplasmic cells. The transmission of a few randomly selected clones of mtDNA into buds is a possible mechanism to establish homoplasmy (23).

Greenhouse monitoring experiments were performed in this study to examine the stability of resistance after the selection pressure of QoI fungicides was removed. Interestingly, molecular studies indicated that the proportion of mutated sequences in cytochrome $b$ gene decreased over time in populations of the pathogen cucumber downy mildew, despite the fact that bioassay data indicated that resistance was still maintained. It is very likely that fungicide performance is lost even when low proportions of resistant strains are included in pathogen populations as described below. It also may be possible that the homoplasmic mutated sequences in the cytochrome $b$ gene have reverted to the heteroplasmic status to include the wild-type sequences gradually over time in the absence of the fungicidal selection pressure (Fig. 4). Gisi et al. (14) wrote that the evolution of QoI resistance at an individual level probably depends on early mitotic events such as mutation rate and repair mechanisms, as well as the process of transition from hetero- to homoplasmic cells, as a result of intracellular selection. Additionally, it also has been reported that the G143A had a slightly deleterious effect on the cytochrome $b c 1$ function in the Qo site of $V$. inaequalis, Podosphaera xanthii, and Pythium megasperma; however, this was not observed in B. graminis (7). The G143A mutation also might affect the fitness of pathogens differentially. Most recently, Fisher and Meunier (8) described that the mutation G143A had no adverse effect on the catalytic activity of the cytochrome $b c 1$ complex in yeast; however, the mutation Y136W did have a slight deleterious effect on $b c 1$ activity. This mutation also has been found in QoI-resistant isolates of cucumber powdery mildew fungus (19).

In cucumber powdery mildew, QoI-resistant isolates appear to have declined following the withdrawal of the fungicides. However, resistant isolates rapidly recovered when azoxystrobin was applied in a single application for the control of Corynespora leaf spot. The behavior of QoI-resistant isolates of Pseudoperonospora cubensis also was monitored in the following crop (13). In cucumber greenhouses, where the ratio of resistant isolates was as low as $0.03 \%$, the ratio increased from 47 to $99 \%$ after one application of azoxystrobin. Recently, Markoglou et al. (25) mentioned that a significant reduction of pyraclostrobin resistance was observed in laboratory mutants of Botrytis cinerea when these mutants were grown on a medium without pyraclostrobin, indicating intracellular selection of the wild-type (sensitive) mitochon-

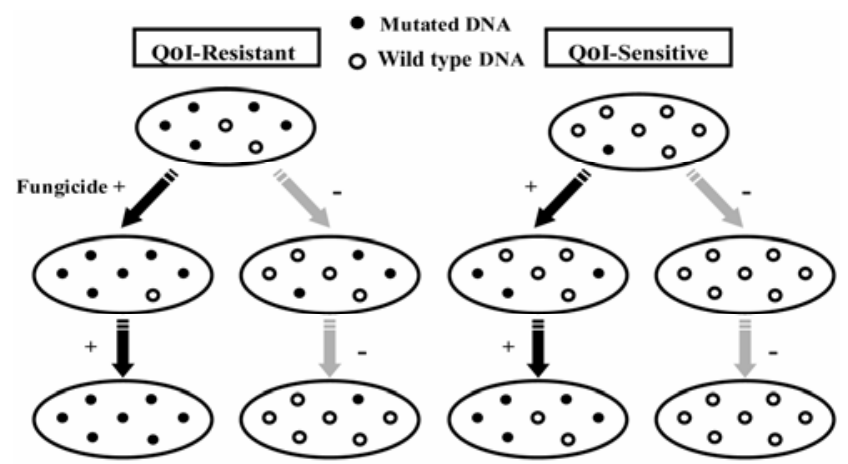

Fig. 4. Hypothetical scheme of effects of presence (+) and absence (-) of QoI fungicide selection pressure on heteroplasmic status of mitochondrial cytochrome $b$ gene in some fungi. 
dria. However, the high level of resistance to pyraclostrobin rapidly returned once the mutants were subcultured on pyraclostrobin-amended media. These observations indicated that QoI resistance management is difficult to achieve once it has appeared under greenhouse conditions in particular.

Fraaije et al. (12) measured the frequency of the G143A mutation in the cytochrome $b$ gene of barley powdery mildew (Blumeria graminis f. sp. hordei) populations obtained from field experiments. To detect QoI-sensitive and -resistant alleles, a 5'nuclease-based real-time PCR assay was developed using allelespecific minor-groove-binder-conjugated TaqMan probes labeled with different reporter dyes. The ratio of the dyes then was used to calculate the allele frequency. Methodologies based on realtime allele-specific PCR using the fluorescent dye SYBR Green I could easily detect a heteroplasmic G143A mutation at a frequency of at least 1 in 10,000, which is most likely sensitive enough to detect a point mutation in a mitochondrial genome within a single spore (10). The same method also was used in Plasmopara viticola, the causal agent of grapevine downy mildew, and samples sensitive to QoI fungicides contained $<0.1 \%$ of the mutant allele, whereas resistant samples contained $>2 \%$ (31). The results indicated that the threshold ratio of the mutant allele will be $\approx 1$ to $2 \%$ in cytochrome $b$ genes, potentially leading to a decrease in fungicide efficacy. The present article shows that the protective efficacy of a full dose of azoxystrobin decreased when populations of cucumber powdery mildew, downy mildew, or Corynespora leaf spot fungus contained resistant isolates at $10 \%$, although the levels of decline varied according to the differences in disease pressure. This is similar to results shown in grapevine downy mildew, where the efficacy of fenamidone decreased to approximately half when resistant populations included resistant alleles at $\approx 10 \%$ in the inoculum source (22).

For the quantification of mutant allele in the cytochrome $b$ gene, we first used a fluorescence bio-imaging analyzer (FMBIO) which originally was used to screen for mitochondrial 3243 mutation in humans (35). This mutation in the mtDNA specifying tRNA is a cause of diabetes mellitus. Using the FMBIO, the mutant alleles from QoI-resistant isolates of cucumber downy mildew could be detected at a $1 \%$ level. However, detection sensitivity using conventional ethidium bromide staining was $\approx 10$ times lower, indicating that the conventional PCR-RFLP methods may overlook the existence of QoI-resistant isolates in fungal populations. In 2004 and 2005, a number of single-spore isolates of cucumber powdery mildew fungus were obtained within Japan and many of them were found to be highly resistant to azoxystrobin using a leaf disk assay. However, the G143A mutation of cytochrome $b$ gene was seldom detected by gel staining PCRRFLP methods or by sequencing of the PCR products (H. Ishii and W.-H. Chung, unpublished data). Quantification of the wildtype and mutant alleles is currently under investigation.

\section{ACKNOWLEDGMENTS}

We thank H. Sugiyama, J. A. Kita-Tsukuba, and S. Ishikawa, Tochigi Agricultural Experiment Station, T. Amano, ZEN-NOH Agricultural R\&D Center, and M. Fukaya, Akita Fruit Tree Experiment Station, for sampling diseased material and supplying fungal isolates; and J. M. Fountaine, National Institute for Agro-Environmental Sciences, for a critical reading of this manuscript.

\section{LITERATURE CITED}

1. Avila-Adame, C., Olaya, G., and Köller, W. 2003. Characterization of Colletotrichum graminicola isolates resistant to strobilurin-related QoI fungicides. Plant Dis. 87:1426-1432.

2. Barr, C. M., Neiman, M., and Taylor, D. R. 2005. Inheritance and recombination of mitochondrial genomes in plants, fungi and animals. New Phytol. 168:39-60.

3. Bartlett, D. W., Clough, J. M., Godwin, J. R., Hall, A. A., Hamer, M., and Parr-Dobrzanski, B. 2002. The strobilurin fungicides. Pest Manag. Sci.
58:649-662.

4. Bäumler, S., Sierotzki, H., Gisi, U., Mohler, V., Felsenstein, F. G., and Schwarz, G. 2003. Evaluation of Erysiphe graminis f. sp. tritici field isolates for resistance to strobilurin fungicides with different SNP detection systems. Pest Manag. Sci. 59:310-314.

5. Brown, W. M., George, M., Jr., and Wilson, A. C. 1979. Rapid evolution of animal mitochondrial DNA. Proc. Natl. Acad. Sci. USA 76:1967-1971.

6. Date, H., Kataoka, E., Tanina, K., Sasaki, S., Inoue, K., Nasu, H., and Kasuyama, S. 2004. Sensitivity of Corynespora cassiicola, causal agent of Corynespora leaf spot of cucumber, to thiophanate-methyl, diethofencarb and azoxystrobin. Jpn. J. Phytopathol. 70:10-13. (In Japanese with English abstract)

7. Fisher, N., Brown, A. C., Sexton, G., Cook, A., Windass, J., and Meunier, B. 2004. Modeling the Qo site of crop pathogens in Saccharomyces cerevisiae cytochrome $b$. Eur. J. Biochem. 271:2264-2271.

8. Fisher, N., and Meunier, B. 2005. Re-examination of inhibitor resistance conferred by Qo-site mutations in cytochrome $b$ using yeast as a model system. Pest Manag. Sci. 61:973-978.

9. Fraaije, B. A., Burnett, F. J., Clark, W. S., Motteram, J., and Lucas, J. A. 2005. Resistance development to QoI inhibitors in populations of Mycosphaerella graminicola in the UK. Pages 63-71 in: Modern Fungicides and Antifungal Compounds IV. H. W. Dehne, U. Gisi, K. H. Kuck, P. E. Russell, and H. Lyr, eds. BCPC, Alton, United Kingdom.

10. Fraaije, B. A., Butters, J. A., Coelho, J. M., Jones, D. W., and Hollomon, D. W. 2002. Following the dynamics of strobilurin resistance in Blumeria graminis f. sp. tritici using quantitative allele-specific real-time PCR measurements with the fluorescent dye SYBR Green I. Plant Pathol. 51:45-54.

11. Fraaije, B. A., Butters, J. A., and Hollomon, D. W. 2000. In planta genotyping of Erysiphe graminis f. sp. tritici isolates for strobilurinresistance using a fluorometric allele-specific PCR assay. Pages 401-406 in: Proc. BCPC Conf. Pests Dis. BCPC, Farnham, United Kingdom.

12. Fraaije, B. A., Lucas, J. A., Clark, W. S., and Burnett, F. J. 2003. QoI resistance development in populations of cereal pathogens in the UK. Pages 689-694 in: Proc. BCPC Int. Congr. Crop Sci. Technol. Glasgow. BCPC, Farnham, United Kingdom.

13. Fuji, M., Takeda, T., Uchida, K., and Amano, T. 2000. The latest status of resistance to strobilurin type action fungicides in Japan. Pages 421-426 in: Proc. BCPC Conf. Pests Dis. Brighton. BCPC, Farnham, United Kingdom.

14. Gisi, U., Sierotzki, H., Cook, A., and McCaffery, A. 2002. Mechanisms influencing the evolution of resistance to Qo inhibitor fungicides. Pest Manag. Sci. 58:859-867.

15. Heaney, S. P., Hall, A. A., Davies, S. A., and Olaya, G. 2000. Resistance to fungicides in the QoI-STAR cross-resistance group: Current perspectives. Pages 755-762 in: Proc. BCPC Conf. Pests Dis. Brighton. BCPC, Farnham, United Kingdom.

16. Inada, M., Furuta, A., and Yamaguchi, J. 2004. Occurrence of azoxystrobin-resistant strains of Glomerella cingulata, the causal fungus of strawberry anthracnose. (Abstr. in Japanese) Jpn. J. Phytopathol. 70:253.

17. Ishii, H. 2002. DNA-based approaches for diagnosis of fungicide resistance. Pages 242-259 in: Agrochemical Resistance-Extent, Mechanism, and Detection. J. M. Clark, and I. Yamaguchi, eds. Am. Chem. Soc., Washington, DC.

18. Ishii, H. 2005. Resistance management strategies for fungicides. Pages 280-288 in: Environmental Fate and Safety Management of Agrochemicals. J. M. Clark, and H. Ohkawa, eds. Am. Chem. Soc., Washington, DC.

19. Ishii, H., Fraaije, B. A., Sugiyama, T., Noguchi, K., Nishimura, K., Takeda, T., Amano, T., and Hollomon, D. W. 2001. Occurrence and molecular characterization of strobilurin resistance in cucumber powdery mildew and downy mildew. Phytopathology 91:1166-1171.

20. Ishii, H., Sugiyama, T., Nishimura, K., and Ishikawa, Y. 2002. Strobilurin resistance in cucumber pathogens: persistence and molecular diagnosis of resistance. Pages 149-159 in: Modern Fungicides and Antifungal Compounds III. H.-W. Dehne, U. Gisi, K. H. Kuck, P. E. Russell, and H. Lyr, eds. AgroConcept, Bonn.

21. Kim, Y.-S., Dixon, E. W., Vincelli, P., and Farman, M. L. 2003. Field resistance to strobilurin (QoI) fungicides in Pyricularia grisea caused by mutations in the mitochondrial cytochrome b gene. Phytopathology 93:891-900.

22. Lacombe, J.-P. 2003. Behaviour of association of fenamidone and fosetyl$\mathrm{Al}$ in relation to QoI-resistant downy mildew. Phytoma 560:45-50.

23. Ling, F., and Shibata, T. 2004. Mhr1p-dependent concatemeric mitochondrial DNA formation for generating yeast mitochondrial homoplasmic cells. Mol. Biol. Cell 15:310-322.

24. Ma, Z., Felts, D., and Michailides, T. J. 2003. Resistance to azoxystrobin in Alternaria isolates from pistachio in California. Pestic. Biochem. Physiol. 77:66-74.

25. Markoglou, A. N., Malandrakis, A. A., Vitoratos, A. G., and Ziogas, B. N. 
2006. Characterization of laboratory mutants of Botrytis cinerea resistant to QoI fungicides. Eur. J. Plant Pathol. 115:149-162.

26. McGrath, M. T., and Shishkoff, N. 2003. First report of the cucurbit powdery mildew fungus (Podosphaera xanthii) resistant to strobilurin fungicides in the United States. Plant Dis. 87:1007.

27. Miguez, M., Reeve, C., Wood, P. M., and Hollomon, D. W. 2003. Alternative oxidase reduces the sensitivity of Mycosphaerella graminicola to QoI fungicides. Pest Manag. Sci. 60:3-7.

28. Nakazawa, T., and Asami, K. 1995. Mitochondria, 2nd ed. Tokyo University Press, Tokyo.

29. Sierotzki, H., Parisi, S., Steinfeld, U., Tenzer, I., Poirey, S., and Gisi, U. 2000. Mode of resistance to respiration inhibitors at the cytochrome bc1 enzyme complex of Mycosphaerella fijiensis field isolates. Pest Manag. Sci. 56:833-841.

30. Sierotzki, H., Wullschleger, J., and Gisi, U. 2000. Point mutation in cytochrome $b$ gene conferring resistance to strobilurin fungicides in Erysiphe graminis f. sp. tritici field isolates. Pestic. Biochem. Physiol. 68:107-112.

31. Sirven, C., Gonzalez, E., Bufflier, E., Latorse, M. P., and Beffa, R. 2002.
PCR-based method for detecting mutation allele frequencies for QoI resistance in Plasmopara viticola. Pages 823-828 in: Proc. BCPC Conf. Pests Dis. Glasgow. BCPC, Farnham, United Kingdom.

32. Yamaguchi, J. 2002. DMI-fungicide-resistant isolates of Mycovellosiella nattrassii Deighton, causal fungus of leaf mold of eggplant. Pages 29-35 in: (Abstr.) 12th Symp. Res. Com. Fungic. Resist. Osaka. (In Japanese with English abstract)

33. Yano, K., and Kawada, Y. 2003. Occurrence of strobilurin-resistant strains of Mycovellosiella nattrassii, causal fungus of leaf mold of eggplants. Jpn. J. Phytopathol. 69:220-223. (In Japanese with English abstract)

34. Ypema, H. L., and Gold, R. E. 1999. Kresoxim-methyl: Modification of a naturally occurring compound to produce a new fungicide. Plant Dis. 83:4-19.

35. Yu, G. S. P., Otabe, S., and Niwa, M. 1996. A sensitive fluorescent assay for the detection and quantification of mitochondrial 3243 mutation. Jpn. J. Clin. Pathol. 44:778-782.

36. Zheng, D., Olaya, G., and Köller, W. 2000. Characterization of laboratory mutants of Venturia inaequalis resistant to the strobilurin-related fungicide kresoxim-methyl. Curr. Genet. 38:148-155. 